\title{
Developing a methodology for assessing the risk of hostile takeover of a motor transport enterprise and measures to prevent it
}

\author{
Nesterenko V. Yu. ${ }^{1}$, Chevychelova O. O. ${ }^{1}$ \\ ${ }^{1}$ Kharkiv National Automobile and Highway University, Ukraine
}

\begin{abstract}
Problem. Mergers and acquisitions are traditional processes of redistribution of property rights in a market economy. Mergers are often used by companies to gain control over larger market segments and increase performance efficiency. The acquisition process is not always desirable for the target company and is often used to establish control over its assets. Thus, the problems of assessing the risk of hostile takeover of the enterprise and its prevention are extremely relevant at the current stage, especially in the transport sector of Ukraine. Goal. The goal of the work is to develop the methodology for assessing the risk of hostile takeover of a motor transport enterprise and suggest methods for preventing its occurrence. Methodology. During the study, the following research methods have been used: analysis and synthesis, logical analysis. Information resources of the study are electronic information resources and periodic publications. Results. The risk of hostile takeover of an enterprise is the probability that the enterprise will become the takeover target through the legal actions and methods taken by the acquirer, but the acquisition procedure itself is against the wishes of the target's board. The list of factors that determine the attractiveness of the potential acquisition target includes: the attractiveness of the enterprise in terms of its financial results and performance, the enterprise is not public, it occupies a considerable market segment, the enterprise operates as a joint-stock company, it is attractive in terms of further resale of its assets, the prospects of the industry in which the enterprise operates. According to the results of the studies assessing the risk level of hostile takeover of the group of motor transport enterprises, it has been revealed that $45 \%$ of enterprises are in the medium risk group. The following list of measures aimed at defending motor transport enterprises against hostile takeovers has been developed: the formation of optimal share capital structure; share consolidation when the majority shareholder holds the controlling interest; carrying out a sound dividend policy, the continuous monitoring of amounts and maturity dates of accounts payable, preventing the risk of arousing the counterparties' interest in the resale of debt obligations of the enterprise to others. Originality. The methodology for assessing the risk of hostile takeover of a motor transport enterprise and reasonable measures to prevent its occurrence have been proposed. Practical value. The proposed recommendations can be used by the owners and management of motor transport enterprises to build an effective system for preventing potential hostile takeovers.
\end{abstract}

Key words: merger, hostile takeover, risk, motor transport enterprise, share capital, accounts payable.

\section{Introduction}

The issues of mergers and acquisitions of enterprises have been relevant for many years of market relations in Ukraine. An interesting feature of the domestic situation is that the research problem affects all fields of both material and non-material spheres of production, as well as service sector enterprises. However, whereas a merger with another company is in many cases a development-friendly procedure, an acquisition is not always friendly towards the target company. Therefore, the issues of assessing the risk of hostile takeover of the enterprise and its prevention are extremely relevant at the current stage, especially in the transport sector of Ukraine.

\section{Analysis of publications}

At different times, a very large number of domestic and foreign researchers devoted their 
works to the study of mergers and acquisitions [1-6]. Some researchers were engaged in defining the concept of hostile takeover and carrying out the assessment of its similarity with the concept of raiding $[7,8]$. A large number of studies are devoted to the evaluation of statistical indicators of mergers and acquisitions and identification of trends in their further expansion on the basis of global trends $[9,10]$. A significant number of researchers consider mergers and acquisitions in terms of corporate security management of the enterprise and focus their research exclusively on joint-stock companies [11-15].

\section{Purpose and Tasks}

The purpose of the work is to develop the methodology for assessing the risk of hostile takeover of a motor transport enterprise and suggest methods for preventing its occurrence.

In accordance with the purpose of the study, the concepts of hostile takeover of the enterprise, the risk of hostile takeover of the enterprise have been identified, the list of performance related factors that determine the degree of risk under consideration has been developed, and the methodology for assessing the risk of hostile takeover of the enterprise has been suggested. For motor transport enterprises that are at risk of hostile takeovers, the analysis of the threats to their performance, which increase the likelihood of takeovers, has been conducted and preventive and protective measures have been substantiated.

The market type of functioning of the national economy involves the expansion of mostly private ownership upon enterprises and their assets. Under unstable economic conditions, almost all developed economies of the world underwent a stage of redistribution of property. This process, on the one hand, is evidence of the immaturity of the economic system and the legal framework in the country, but, on the other hand, is a mandatory stage in the development of market economy, and as a result it brings its development to a fundamentally new level.

Over the last two decades, Ukraine has undergone several waves of mergers and acquisitions. The period 2003-2004 can be described as the period of the first wave of the spread of mergers and acquisitions, with the predominance of hostile acquisitions. It was during this period that the use of such a concept as raiding became widespread. However, a clear understanding of the differences or similarities between acquisition processes and raiding did not exist then. The next wave is the period of 2008-
2009. This was already a more civilized stage of redistribution of property in Ukraine. It was during this period that the extremely important Law of Ukraine "On Joint-Stock Companies" was adopted, which allowed bringing under regulation a significant number of legal issues that had previously contributed to a considerable spread of raider seizures of enterprises. During this period, due to more appropriate legal regulations, there was a reduction in the number of raider seizures of enterprises, as well as a considerable spread of civilized mergers of enterprises. The latest wave in the development of mergers and acquisitions has been experienced since 2010 . The stage of stabilization of mergers and acquisitions is currently under way. A considerable expansion of the legal framework governing the activities of enterprises in Ukraine made it possible to legalize mergers and acquisitions of enterprises for the most part. Therefore, under present-day conditions it is no longer correct to use the terms 'raider seizure' and 'hostile takeover' interchangeably.

Under current conditions, a hostile takeover is a forced acquisition where the acquirer takes over the target company in a lawful manner.

A raider seizure is an illegal takeover of other companies. Thus, this process is not under the control of the company's management, but it falls under the exclusive jurisdiction of law enforcement agencies.

Further research will focus on the study of the hostile acquisition process, as such, the management of which is under the control of the owners and the management of the enterprise.

According to the fact that each enterprise in the course of its activities, and especially if it operates as a joint-stock company, may face a potential threat of a hostile takeover. In order to adequately respond to the situation it is necessary to assess the level of risk arising in the course of enterprise activities. In this regard, the industry characteristics of the enterprise should be taken into account when assessing the risk under consideration.

Thus, further in the study the risk of hostile takeover of the enterprise is understood to mean the probability that the company may become the target of a takeover, which is accomplished by the acquirer in a lawful manner, but the acquisition procedure is carried out against the wishes of the owner of the target company.

In the process of studying the problem of a hostile takeover of the enterprise, the list of factors that determine its attractiveness for a potential takeover has been compiled, namely: 
the attractiveness of the enterprise in terms of its financial results and performance; the enterprise is not public, so it is not widely known to the general public; the enterprise occupies a considerable market segment compared to other competitors; the enterprise operates as a jointstock company; the enterprise is attractive in terms of further resale of its assets; the prospects of the industry in which the enterprise operates.

Assessing the attractiveness of the enterprise by each of these factors using the methods of mathematical modelling makes it possible to build an appropriate model that allows us to estimate the overall probability of hostile takeover of the enterprise. It can be shown as follows:

$$
\begin{aligned}
K_{r}= & 0.2257 b_{1}^{\prime}+0.2314 b_{2}^{\prime}+0.1419 b_{3}^{\prime}+ \\
& +0.1297 b_{4}^{\prime}+0.2403 b_{5}^{\prime}+0.031 b_{6}^{\prime}
\end{aligned},
$$

where $K_{r}$ is the indicator of the risk of hostile takeover of the enterprise; $b_{1}$ is the indicator of assessing the attractiveness of the enterprise by the financial performance factor; $b_{2}$ is the indicator of assessing the attractiveness of the enterprise by the publicity; $b_{3}$ is the indicator of assessing the attractiveness of the enterprise by the occupied market segment; $b_{4}$ is the indicator of assessing the attractiveness of the enterprise by belonging to the joint-stock form of ownership; $b_{5}$ is the indicator of assessing the attractiveness of the enterprise in terms of further resale of the assets; $b_{6}$ is the indicator of assessing the attractiveness of the enterprise according to industry prospects.

The coefficient $K_{r}$ can be within the range of values from 0 to 1 . If its value goes towards 1 it means that there is an increase in risk associated with a hostile takeover.

To evaluate the degree of risk of hostile takeover by $K_{r}$ indicator, the following scale has been developed:

- when the indicator value does not exceed 0.5 it means that the enterprise is not a potential acquisition target at the current stage;

- when the indicator value reaches the level of 0.7 it means that the enterprise is a potential acquisition target, so the management and owners of the company should analyse its weaknesses, especially in terms of legal support of its activities and the quality of registration of property rights to tangible and intangible assets;

- when the values of indicator $K_{r}$ range between 0.7 and 1 it means that there exists a potentially high level of risk of hostile takeover of the enterprise, so it should immediately implement measures to protect the property.

According to the proposed indicator of assessing the risk of hostile takeover, the study has been conducted on the group of enterprises that operate as joint-stock companies in the motor transport sector of Ukraine's economy. The enterprises were selected so that they represent different regions of Ukraine.

The results of the studies assessing the risk level of hostile takeover of 10 motor transport enterprises, have revealed that the sector is not subject to high level of risk at the current stage. However, $45 \%$ of enterprises are in the medium risk group, it means that some aspects of their activities can result in a situation where they may become acquisition targets.

According to the analysis of the factors, which contributed to the increase in the level of risk associated with the activities of motor transport enterprises and according to the results of intermediate calculations of the model, the following tendencies can be seen: the enterprise is attractive in terms of further resale - all of the enterprises that are in a risk zone are attractive in this respect, mainly by reason of their sizable land property; enterprises are not public regarding their activities, they are not widely known to the general public of their regions, their activities are not under public control and therefore the risk of being taken over without wide public resonance is quite high; attractive financial position $-60 \%$ of motor transport enterprises, which are in a risk zone, are financially stable and relatively financially secure, this fact significantly contributes to increasing interest among potential acquirers.

Let us analyse what exactly should be done by the enterprise management, if the results of calculating the risk rating of hostile takeover have revealed that there exists a high risk for the enterprise.

If it is determined that the company may be a potential target of a hostile takeover, it is necessary to analyse what characteristics of its activities can be used to implement the acquisition procedure.

The evidence from international experience gained in implementing acquisitions of enterprises suggests that the following approaches can be used in this respect. These are the following groups of actions: the use of share capital of the enterprise, its structure regarding the correlation between majority and minority shareholders; putting pressure on the enterprise through its accounts payable; putting pressure on the enter- 
prise through intangible assets that it uses, challenging the legality of their usage and registration of property rights to them; the actions to challenge the legality of privatization procedures, if the enterprise was established using such mechanisms.

Considering the fact that the joint-stock form of ownership is an additional dimension of its vulnerability to the risk of hostile takeover, we can analyse what methods can be used to implement the takeover through share capital.

The share capital factor is extremely relevant for motor transport enterprises, because the vast majority of them, according to statistics, operate under various forms of ownership.

Thus, the following methods can be used to accomplish a hostile takeover through share capital: redistribution of shares by establishing control over the shares of minority shareholders; the deliberate creation of conflict situations between majority shareholders; physical and legal blocking of ordinary shares during the General Meeting of Shareholders; using nominee shareholders and enterprise managers.

It should also be noted that the method of manipulation with the register of enterprise shareholders can be used. But considering the trend towards legalization of mergers and acquisitions in Ukraine, this method can be classified as criminal, i.e. that used during the raider seizure. That is why this method should not be under consideration when studying the procedure of legal hostile takeovers at the current stage.

It should be mentioned that there are certain actions of owners and the management of the enterprise that increase the likelihood of takeover through share capital.

If the activity of the enterprise is constantly declared by the owners as loss-making, i.e. shareholders do not receive dividends, or decisions are made to use all profits of the enterprise for purposes other than dividend payments, then for minority shareholders ownership of such shares ceases to be attractive and profitable. Such situation contributes to the motivation for the sale of their shares to a potential acquirer.

It is also risky when the controlling interest is owned by several majority shareholders, even if they are members of the same family - such situation is very common for motor transport enterprises in Ukraine.

In situations like this, methods of creating artificial conflicts between majority shareholders or taking advantage of existing informal conflicts between them can be very effective.
In that case, an additional risk factor is the situation when the shares of the enterprise under consideration are not the only source of income for their holder, so he may consider a takeover bid.

The practice of using nominee shareholders is also risky, i.e. the formal registration of shares in nominee owners, which operate under the control of the real owner. It should be noted that in such cases there is always a high probability of inappropriate actions of the nominee shareholder, who legally owns all the rights of a real majority shareholder.

In particular, consideration should be given to such method of establishing control over the enterprise as using its accounts payable. This is one of the most effective and legally sound methods of takeover. The implementation of this method for a hostile takeover of the enterprise is possible due to the following actions:

- repurchase of debt obligations of the enterprise from its creditors;

- creating artificial conditions for the formation of accounts payable by the enterprise in order to force it to use credit resources and use property as subject of a pledge.

To predict the situation of pressure on the enterprise due to accounts payable, it is necessary to avoid in its activities the occurrence of the following aspects: the low level of trust and contractual relations with the main contractors; weakened control over accounts payable by the enterprise management; low motivation of enterprise management team; unfavourable geographical position of the enterprise in terms of infrastructure development that can be used when arranging a hostile takeover.

In the current circumstances, the vast majority of enterprises should be very careful about using intangible assets when performing their activities. Certain legal irregularities and ignoring appropriate registration of property rights to intangible assets by enterprise owners have created an efficient instrument in conducting hostile takeovers through intangible assets.

Risk factors for the enterprise in the context of this method of acquisition are the following: the usage of intangible assets without registering ownership of them; the enterprise performance implies the mandatory use of certain intangible assets, which are difficult to replace; the aspects of reputation are extremely important for the enterprise performance.

Thus, all the above-mentioned aspects can make the enterprise very vulnerable to changes in its intangible assets, and apparently, the methods of a hostile takeover through intangible 
assets can be effectively used to create instability at the enterprise.

Such a takeover can be implemented as follows: the acquirer may register the ownership of intangible assets and, as a consequence, he may further demand for payment of compensation for illegal usage of assets and copyright infringement, namely he may create artificial accounts payable at the enterprise and exert a negative effect on its reputation;in case there are no other alternative intangible assets the acquirer may require the enterprise to pay for the usage more than the enterprise can afford according to its financial capacity.

The analysis of motor transport enterprises that belong to the group under consideration allows us to obtain the following conclusions on the most probable and effective methods of hostile takeovers in the motor transport industry.

The vast majority of motor transport enterprises have threatening factors that determine the possibility of being taken over due to minority shareholders, who in most companies are dissatisfied with the dividend policy, and therefore do not have much interest in holding shares.

Another weakness of motor transport enterprises is accounts payable, especially for the goods provided to them (mainly fuel and lubricant materials and spare parts), as well as for motor vehicles purchased on credit. Debts for fuel can significantly reduce mutual trust between counterparties, and therefore the situation can be used for buying up accounts payable of enterprises.

A further threat to motor transport enterprises in terms of the likelihood of hostile takeover is the presence of several majority shareholders, especially if their total share of stocks is not a controlling interest. This situation can be used by the acquirer to effectively implement the full range of methods of hostile takeover through share capital.

The analysis of information on the activities of the group of motor transport enterprises under consideration has revealed that most of them have common shortcomings in the statutory documents, as well as procedures of registration and voting of shareholders at the general meetings, decision-making, allocation of responsibilities between governing bodies, limiting governance for making certain decisions.

It should be noted that most of these shortcomings can be rectified by the introduction and strict compliance with the requirements of the Law of Ukraine "On Joint-Stock Companies". Hostile takeovers due to accounts payable can be prevented by complying with the civilized rules of doing business, building long-term relationships with counterparties with a high level of trust.

According to the particular actions that should be primarily taken by the owners of motor transport enterprises for defending the enterprise against a hostile takeover, the following measures can be specified: constructing the optimal structure of the share capital regarding the correlation between share of stocks of majority shareholders; in the event that the enterprise has only one majority shareholder, and other shares are distributed among minority shareholders, it is necessary to achieve consolidation, under which the majority shareholder holds the controlling interest, until the existing structure of share capital isn't used for hostile takeover; in order to provoke shareholders' interest in holding their shares, it is necessary to pursue a transparent and sound dividend policy to exclude the possibility of buying up shares for accomplishing hostile takeovers through share capital; the continuous monitoring of amounts and maturity dates of accounts payable, as well as preventing the risk of arousing the counterparties' interest in the resale of debt obligations of the enterprise to others.

Acting in advance of a future situation considering the diagnostics and monitoring of weaknesses of the performance, which create preconditions for hostile takeovers, gives owners and the management of motor transport enterprises an opportunity to protect their enterprise effectively and to prevent the hostile takeover.

\section{Conclusion}

Mergers and acquisitions are considered to be a logical stage in the development of market relations, which is underway at various stages of all national economies. From the point of view of building an effective enterprise management system, it is important to monitor the probability of hostile takeover of the enterprise, especially if it operates as a joint-stock company. Such monitoring can be carried out by calculating the risk rating of a hostile takeover. When assessing the level of risk for the group of motor transport enterprises, it has been revealed that the sector is subject to an average level of risk of hostile takeovers. This is grounds for the need to study the methods, by which it is possible to implement the acquisition of motor transport enterprises. According to the results of the study, one of the main factors contributing to an increase in the likelihood of hostile takeovers of enterprises 
in the transport sector of Ukraine is improper structure of share capital regarding distribution of majority shareholders' shares and the controlling interest, which gives authority to make key decisions concerning the management of the enterprise and the alienation of its property.

It has been found that in many motor transport enterprises, the share capital is distributed among a considerable number of minority shareholders, but the dividend policy pursued by motor transport enterprises does not provoke shareholders' interest in holding their stakes.

The study has also revealed that modern motor transport enterprises operate with significant amount of accounts payable, which mainly consists of debts for supplied fuel and lubricant materials and spare parts, as well as considerable amount of accounts payable, which includes motor transport enterprises' debts for the acquisition of motor vehicles at the expense of credit resources. This situation contributes to the effectiveness of the methods of hostile takeovers of enterprises through accounts payable, in particular due to buying up accounts payable of motor transport enterprises from their counterparties. Thus, motor transport enterprises that operate with large amount of credit obligations, should avoid debts to suppliers and settle all overdue payments on loans for labour instruments on time, as well as build long-term mutually beneficial relationships with counterparties.

\section{Conflict of interests}

The authors declare that there is no conflict of interests regarding the publication of this paper.

\section{References}

1. Akram, J, Shadid, MK. (2016). The Impact of Critical Factors on Mergers and Acquisition in Coverging ICT Industry. Journal of Information Engineering and Application.

2. Candra, A., Priyarsono, D., Zulbainarni N., Sembel N. (2021). Literature Review on Merger and Acquisition. Special Issue: Managing Economic Growth in Post COVID Era: Obstacles and Prospects, Vol. 39, No. 4. https://dx.doi.org/10.25115/eea.v39i4.4627.

3. Fatih, A, Cagle, MN. (2015). Critical Success Factors in Merger and Acquisition Strategies: Evaluation of Turkish Market.

4. Fidrmuc, JP., Xia C. (2017).. M\&A Dela Initiation and Manager Motivation. Journal of Corporate Finance. Elsevier

5. Gupta, P. (2012). Mergers and Acquisition (M\&A): The Strategic Concept for The Nuptials of Corporate Sectors. Innovative Journal of Busi- ness and Management 1: 4 July - Aug (2012) 60 - 68. ISSN No. 22274947.

6. Holloway, I, Lee, SH, Shen, T. (2016). Private Equity Firm Heterogeneity. International Review of Economic and Finance, 44, 118-140.

7. Панасенко, Р. А. (2017). Дефеніція рейдерства та його співвідношення із суміжними поняттями. Вісник Луганського державного університету внутрішніх справ імені Е.О. Дідоренка, 3, 95-102. Panasenko, R. (2017). Defenitsiia reiderstva ta yoho spivvidnoshennia iz sumizhnymy poniattiamy. [The definition of raiding and its relationship with related concepts]. Bulletin of Luhansk State University of Internal Affairs named after E.O. Didorenko, 3, 95-120.

8. Бутрин-Бока, Н. С. (2016). Правове закріплення визначення поняття корпоративні права за законодавством України. Актуальні проблеми вітчизняної юриспруденції, 2, 54-57. ButrynBoka, N. (2016). Pravove zakriplennia vyznachennia poniattia korporatyvni prava za zakonodavstvom Ukrainy. [Legal consolidation of the definition of corporate rights under the legislation of Ukraine], 2, 54-57.

9. Гамма, Т. М. (2016). Особливості та перспективи розвитку ринку M\&A в Україні. Науковий вісник Мукачівського державного університету. Сер.: Економіка, 1, 106-112. Hamma, T. (2016). Osoblyvosti ta perspektyvy rozvytku rynku M\&A v Ukraini. [Peculiarities and perspectives of development of the M\&A market in Ukraine]. Scientific Bulletin of Mukachevo State University. Ser .: Economics,1, 106-112.

10. Тєшева, Л. В., Невдачина, О. І., Гарапко, М. І. (2016). Основні тенденції та пріоритети реорганізації підприємств, спрямованої на їх укрупнення в умовах інституційних трансформацій. Вісник Одеського начіонального університету. Серія: Економіка, 21, 178-181. Tiesheva, L., Nevdachyna, o., Harapko, M. (2016). Osnovni tendentsii ta priorytety reorhanizatsii pidpryiemstv, spriamovanoi na yikh ukrupnennia $\mathrm{v}$ umovakh instytutsiinykh transformatsii. [The main trends and priorities of enterprise reorganization aimed at their consolidation in the context of institutional transformations]. Bulletin of Odessa National University. Series: Economics, 21, 178-181.

11. Луговий, О. (2020). Правове регулювання протидії рейдерству в Україні. Jurnalul juridic national: teorie şi practică, 41(1), 138-142. Luhovyi, O. (2020). Pravove rehuliuvannia protydii reiderstvu v Ukraini. [Legal regulation of counteraction to raiding in Ukraine]. Jurnalul juridic national: teorie şi practică, 41(1), 138-142.

12. Яструбецька, Л. С. (2017). Особливості організації рейдерських захоплень підприємств в Україні. Економіка $i$ суспільство, 9, 1107-1112. Yastrubetska, L. (2017). Osoblyvosti orhanizatsii reiderskykh 
zakhoplen pidpryiemstv v Ukraini. [Peculiarities of the organization of raider seized pidad receptions in Ukraine]. Economy and society, 9, 11071112.

13. Титаренко, С. С. (2016). Соціально-економічні підстави відповідальності за протиправне заволодіння майном підприємств в Україні. Науковий вісник Міжнародного гуманітарного університету. Серія Юриспрудениія, 24, 134-138. Tytarenko, S. (2016). Sotsialno-ekonomichni pidstavy vidpovidalnosti za protypravne zavolodinnia mainom pidpryiemstv $\mathrm{v}$ Ukraini. [Socioeconomic grounds for liability for misappropriation of property of enterprises in Ukraine]. Scientific Bulletin of the International Humanities University. Jurisprudence series, 24, 134-138.

14. Марущак, Я. (2016). Корпоративні суб'єктивні права в комерційних товариствах. Evropský politický a právni diskurz, 5, 123-127. Marushchak, Ya. (2016). Korporatyvni subiektyvni prava $\mathrm{v}$ komertsiinykh tovarystvakh. [Corporate subjective rights in companies]. European political and legal discourse,5, 123-127.

15. Яструбецька, Л. С., Яремик, М. М. (2015). Аналіз особливостей злиття та поглинання підприємств в Україні. Науковий вісник НЛТУ України, 25(7), 239-245. Yastrubetska, L., Yaremyk, M. 92015). Analiz osoblyvostei zlyttia ta pohlynannia pidpryiemstv v Ukraini. [Analysis of the peculiarities of mergers and acquisitions in Ukraine]. Scientific Bulletin of NLTU of Ukraine, 25(7), 239-245.

Valentyna Nesterenko ${ }^{1}$, PhD, Assoc. Prof.

Department of Economics and Entrepreneurship, valentinaonisiforova@gmail.com,

tel.: +38-098-284-09-59,

ORCID: 0000-0001-9899-8427

Olena Chevychelova ${ }^{1}$, Asst. Prof., Department of Foreign Languages, chevychelova910@ukr.net, tel.: +38-097-778-38-08, ORCID: https://orcid.org/0000-0001-5325-5734

${ }^{1}$ Kharkiv National Automobile and Highway University Yaroslava Mudrogo str., 25, Kharkiv, Ukraine, 61002

\section{Розробка методики оцінювання ризику недружнього поглинання автотранспортного підприсмства та заходи його попередження}

Анотація. Проблема. Злиття та поглинання є традиційними процесами перерозподілу прав власності у ринковій економіці. Процес поглинання часто використовуються для встановлення контролю над активами. Отже, проблеми оцінювання ризику недружнього поглинання підприємства та його попередження є надзвичайно актуальними, і особливо у транспортній галузі Украӥни. Мета. Метою роботи є розробка методики оиінювання ризику недружнього поглинання підnриємства автомобільного транспорту та фор- мування пропозицій з попередження його виникнення. Методологія. В ході дослідження використані методи аналізу і синтезу, метод логічного аналізу. Результати. Ризик недружнього поглинання підприємства - ие ймовірність того, щчо підприємство стане об'єктом поглинання з використанням законних дій та методів з боку підприємства - суб'єкта поглинання, але сама процедура поглинання відбувається всупереч бажанню власника підприємства - об'єкта поглинання. Перелік факторів, які визначають привабливість підприємства для потениійного поглинання: привабливість підприємства з точки зору фінансових результатів та показників діяльності, підnриємство не є публічним, підприємство утримує дуже значний сегмент ринку, підприємство функціонує у формі акціонерного товариства, підприємство є привабливим з точки зору подальшого перепродажу його активів, перспективність галузі, в якій функиіонує підприємство. В результаті оцінювання рівня ризику недружнього поглинання групи автотранспортних підприсмств було встановлено, щзо 45\% підприємств потрапили до групи середнього ризику поглинання. Сформовано наступний перелік дій по захисту автотранспортних підприємств від недружнього поглинання: побудова оптимальної структури акиіонерного капіталу; консолідація у мажсоритарного акціонера контрольного пакету акцій; проведення обтрунтованої дивідендної політики, постійний контроль обсягів та строків погашення кредиторської заборгованості, недопущення створення зацікавленості контрагентів у перепродажу боргових зобов'язань підприємства іншим особам. Орихінальність. Запропонована модель оцінювання ризику недружнього поглинання підприємства автомобільного транспорту та обтрунтовані заходи з протидії його виникненню. Практичне значення. Запропоновані рекомендації можуть бути використані власниками та менеджментом автотранспортних підприємств для побудови ефективної системи протидї виникненню ризику недружнього поглинання.

Ключові слова: злиття, недружне поглинання, ризик, автотранспортне підприємство, акиіонерний капітал, кредиторська заборгованість.

Нестеренко Валентина Юріївна ${ }^{1}$, к.е.н., доцент кафедри економіки і підприємництва, valentinaonisiforova@gmail.com, тел.: +38-098-284-09-59,

ORCID: 0000-0001-9899-8427

Чевичелова Олена Олександрівна ${ }^{1}$, ст. викладач кафедри іноземних мов, chevychelova910@ukr.net, tel.: +38-097-778-38-08, ORCID: https://orcid.org/0000-0001-5325-5734

${ }^{1}$ Харківський національний автомобільнодорожній університет, вул. Ярослава Мудрого, 25, м. Харків, Україна, 61002. 